\title{
Foraging, growth and habitat choice in turbid water: an experimental study with fish larvae in the Baltic Sea
}

\author{
Jonna Engström-Öst ${ }^{1,2, *}$, Johanna Mattila ${ }^{3}$ \\ ${ }^{1}$ Finnish Institute of Marine Research, PO Box 2 (Erik Palméns plats 1), 00561 Helsingfors, Finland \\ ${ }^{2}$ Aronia Coastal Research Team at Sydväst University of Applied Sciences and Åbo Akademi University, Raseborgsvägen 9, \\ 10600 Ekenäs, Finland \\ ${ }^{3}$ Husö Biological Station \& Environmental and Marine Biology, Åbo Akademi University, Akademigatan 1, \\ 20500 Åbo, Finland
}

\begin{abstract}
Eutrophication is a large problem in many marine and brackish-water areas. One of the consequences is algae-induced turbidity affecting visually feeding organisms, and behavioural changes of fish and other animals are common in turbid water. The aim of this study was to compare the performance of larval pike Esox lucius in turbid and clear water. We experimentally studied habitat choice, prey attacks and swimming activity of newly hatched larvae in the presence of a predator and competitors in relation to algae-induced turbidity. Our results demonstrated that the larvae spent less time in vegetation, performed more prey attacks and spent less time swimming in turbid water than in clear conditions. The presence of competitors increased the number of prey attacks, while the presence of a visual predator decreased the number of attacks. We also showed that pike larval weight was lower in high turbidity than in low turbidity. Our results show that algae-induced water turbidity affects both direct (i.e. feeding and habitat choice) and indirect qualities (i.e. weight) of pike larvae and may therefore affect larval survival and potentially even recruitment into the population.
\end{abstract}

KEY WORDS: Turbidity $\cdot$ Pike larvae $\cdot$ Habitat choice $\cdot$ Prey attacks $\cdot$ Growth $\cdot$ Shelter $\cdot$ Perception of threat

Resale or republication not permitted without written consent of the publisher

\section{INTRODUCTION}

Algae-induced turbidity has greatly increased in coastal areas worldwide due to nutrient runoffs into rivers, lakes and seas. The increasing amount of nutrients leads to algal blooms and higher turbidity (UtnePalm 2002). With elevated turbidity, light attenuation increases, limiting visibility (Eiane et al. 1999). However, some species benefit from elevated turbidity levels, because their visual acuity is enhanced due to increased scattering of light increasing the contrasts in the water. Algae-induced turbidity within certain levels is desirable, since algae add oxygen and remove nutrients from the water (Boyd 1982). The phenomenon may have both positive and negative effects on the behaviour of visually feeding fish. For a large piscivore that detects its prey from a long distance, increasing turbidity will be more disruptive than for a small planktivore that detects its prey at a shorter distance (Chesney 1989). Negative effects caused by turbidity include decreased reactive distance to prey, changes in the amount or type of prey, lower opportunity for sexual selection in fish with visual mate choice, and decreased growth due to reduced capture success (Järvenpää \& Lindström 2004, Stuart-Smith et al. 2004, Ljunggren \& Sandström 2007). In contrast, positive effects include increased feeding rate due to a lower risk of predation (Gregory \& Northcote 1993). Turbidity may also induce other activities, such as migration, reduced use of shelter and increased use of open water (reviewed by Utne-Palm 2002). Finally, turbidity, as such, may also provide shelter against predators (Maes et al. 1998, Snickars et al. 2004, Engström-Öst et al. 2006).

The pike Esox lucius is an important piscivore in many northern areas and is also an important catch for fishermen in the northern Baltic Sea (Lappalainen 
2002). The pike is considered to be a very adaptive species due to its wide distribution (Casselman \& Lewis 1996), but despite high flexibility, populations have collapsed during the last few years in areas where environmental changes have been considerable (reviewed by Casselman \& Lewis 1996, Nilsson et al. 2004). The Baltic Sea, where our study was performed, has become increasingly turbid during the last few decades (Sandén \& Håkansson 1996).

The aim of this study was to study pike larval behaviour, including habitat choice, foraging and swimming in the presence of a competitor species and a visual predator in an environment with algal turbidity. We also analysed stomach contents and measured larval condition. Finally, weight of pike larvae in high and low turbidity was monitored. We hypothesised that the behaviour of pike larvae, such as habitat choice, is less pronounced in turbid water, because predators are more difficult to detect, and the larvae thus perceive less threat. Further, we expected that open turbid water would be used more frequently than open clear water due to increased protection from visual predators. Pike are usually considered to be sensitive to turbid water (Vøllestad et al. 1986, Craig \& Babaluk 1989, Lehtiniemi et al. 2005), but few studies have investigated the behaviour of larval stages as a consequence of this environmental change. Freshwater, brackishwater and marine species inhabit the Baltic Sea, where this study was conducted. Therefore, all organisms used in the current study (pike larvae, mysid shrimps, copepods) are common species in the Baltic Sea and co-occur within the habitats (Lehtonen 1986, Engström-Öst 2002, Kotta et al. 2004).

\section{MATERIALS AND METHODS}

Study organisms. Larval pike Esox lucius with yolk sacs at $4 \mathrm{~d}$ post hatch (dph) were obtained from a fish hatchery in SW Finland (Trollböle). The larvae originated from 5 females and 5 males, caught from the natural environment. The eggs were fertilised and hatched in river water according to the normal procedures at the hatchery. The larvae were transported in a plastic bag containing oxygen-enriched river water to the Tvärminne Zoological Station. The larvae were acclimated for $2 \mathrm{~h}$ to the ambient temperature and then divided into two 6281 tanks with brackish-water flowthrough (salinity $6.6 \pm 0.07,10^{\circ} \mathrm{C}$, unfiltered). Macroalgae and stones were added to both containers. The larvae were fed with a dense zooplankton community twice a day $\left(32 \pm 6\right.$ prey $\left.\mathrm{ml}^{-1}\right)$. The main species were rotifers Synchaeta sp. and Acartia bifilosa copepod adults and nauplii. Since the fish tanks were outdoors, the light regime was natural, varying between ca.
17:7 $\mathrm{h}$ and 19:5 h light:dark during the study period. The fish were not removed from the tanks until the experiment. Pike are common along the coastline of the brackish Baltic Sea and are well adapted to brackish water (Engström-Öst et al. 2005). Large numbers of stocked pike larvae of freshwater origin are annually released to the brackish Baltic Sea (Selén 1999). Pike usually use habitats with Phragmites australis or Fucus vesiculosus in the Baltic Sea (Lehtonen 1986).

The zooplankton (Synchaeta sp., Acartia bifilosa) that were used as food for the pike larvae were collected with ca. 8 hauls with a $100 \mu \mathrm{m}$ net from 0 to $25 \mathrm{~m}$ depth. Collection was performed daily in an open pelagic area (Storfjärden). Upon arrival in the laboratory, the zooplankton container was transferred to a climate chamber $\left(14\right.$ to $15^{\circ} \mathrm{C}, 16: 8 \mathrm{~h}$ light:dark) and aerated.

The predators (Eurasian perch Perca fluviatilis, total length $\left[L_{T}\right] 18$ to $19 \mathrm{~cm}$ ) were caught from a shallow bay (depth 1 to $2 \mathrm{~m}$ ) with fish traps. The traps were checked twice a day. The perch were kept in an outdoor 6281 tank on a brackish-water flow-through system (similar as above). The perch were fed ad libitum with mysid shrimps once a day. Perch are common predators of pike larvae in the Baltic Sea area (Selén 1999 and references therein).

The competitors (mysid shrimps Neomysis integer) were caught from the littoral zone with a beach seine. The mysids were kept in an aerated $30 \mathrm{l}$ container in the climate chamber and fed once daily ad libitum with natural zooplankton. The temperature and light conditions in the climate chamber were the same as mentioned above. $N$. integer is the most common and widespread mysid shrimp in the Baltic Sea, occupying mainly shallow coastal areas (Kotta et al. 2004).

Turbidity was created using the green flagellate Brachiomonas submarina, diameter $7.5 \mu \mathrm{m}$. We obtained $B$. submarina from the culture collection at Tvärminne Zoological Station, University of Helsinki, where it was cultured in TV2 medium (Hällfors \& Hällfors 1992). The algal culture density was quantified by particle counting (ELZONE particle counter, Particle Data).

Bladder wrack Fucus vesiculosus was collected close to the shoreline from ca. $1 \mathrm{~m}$ depth and detached from the stones with a rake. The filamentous green alga Cladophora glomerata was collected manually from ca. $1 \mathrm{~m}$ depth and was not detached from the stones. The algae were stored under light in the same climate chamber as mentioned above and aerated. After the experiment, C. glomerata was removed from the stones with a blade. All algae were dried on aluminium foil at $60^{\circ} \mathrm{C}$ for $24 \mathrm{~h}$ or until dry and then weighed.

Expt 1: habitat choice in turbid water. Pike larvae were exposed to turbid and clear water and allowed to choose between 2 different habitats in the presence of competitors and/or a predator. The control data (i.e. clear 
water treatment; see Fig. 1) were obtained from Engström-Öst et al. (2007). One pike larva was placed in a 5 l aquarium $(20 \times 28 \times 9 \mathrm{~cm}$, height $\times$ width $\times$ depth $)$ that had been divided into 3 habitats by putting filamentous algae Cladophora glomerata and bladder wrack Fucus vesiculosus at opposite ends of the rectangular aquarium. The third habitat, an open brackish-water area, separated the 2 vegetation patches. The length of each vegetation habitat was ca. $8 \mathrm{~cm}$, and the distance between the 2 habitats was ca. $12 \mathrm{~cm}$. The pike larva was subjected to 1 of the following treatments: (1) 5 competitors present (Neomysis integer), (2) visual contact with a predator (Perca fluviatilis), (3) 5 competitors present + visual contact with a predator or (4) the control (no competitors or predator present). Each pike larva was used only once in 1 video session. The pike larvae were 26 to $31 \mathrm{dph}\left(L_{T}: 14.0 \pm 0.1 \mathrm{~mm}\right.$, weight $\left.[\mathrm{W}]: 0.013 \pm 0.0003 \mathrm{~g}\right)$ during the experimental period. The 2 vegetated habitats were created by attaching $F$. vesiculosus by strings to a plastic net, which was covered by washed commercial fine sand, and by embedding small stones with attached C. glomerata in sand, respectively. Each of the algae took up ca. $1 / 5$ of the volume of the aquarium. The average biomass (dry weight) of $F$. vesiculosus was $2.01 \pm 0.15 \mathrm{~g}$ and that of C. glomerata was $0.14 \pm 0.04 \mathrm{~g}$. The biomass difference depended on the marked morphological differences of the 2 species: $F$. vesiculosus is thick, robust and has an open and highly curved structure, whereas C. glomerata consists of long, thin and simple filaments. The aquarium was filled with filtered brackish water (10 $\mu \mathrm{m}$ filtered, ca. 6 psu).

The pike larvae and mysid shrimps were starved for $74 \pm 4$ min prior to the experiment and were acclimatised to the environment for $10 \mathrm{~min}$. Prior to the acclimatisation, the plankton algae were added to the aquarium to make the water turbid. Chlorophyll (chl) a concentration was $42.7 \pm 3.0 \mathrm{\mu g} \mathrm{l}^{-1}$ in the experimental units, which corresponded to $30 \pm 2.3$ NTU (i.e. very turbid conditions). Turbidity in the Baltic Sea may vary between 0.5 and 45 NTU (Granqvist \& Mattila 2004). The acclimatisation of experimental organisms was performed in a plastic bottle, which was placed in the middle of the aquarium. The bottle had net-covered holes at 1 end and on 1 side to allow water exchange. The mysid shrimps were acclimatised simultaneously with the pike larva in the same bottle. After the acclimatisation, the bottle was carefully emptied in the middle of the aquarium, and $100 \mathrm{ml}$ of dense natural zooplankton community was poured uniformly into the water $\left(32 \pm 6\right.$ prey $\left.\mathrm{ml}^{-1}\right)$. We used 2 Eurasian perch as predators. One of the perch was placed in a separate 191 aquarium $(25 \times 30 \times 25 \mathrm{~cm})$ next to the long side of the rectangular fish larval aquarium so that the pike larva only had visual contact with it. The water temperature in the predator aquaria was $16.7 \pm 0.3^{\circ} \mathrm{C}$.
During the experiment, the pike larvae were filmed for $10 \mathrm{~min}$. The video sessions were recorded at room temperature in 36.5 to $58.9 \mu \mathrm{E} \mathrm{m} \mathrm{m}^{-2} \mathrm{~s}^{-1}$ light. The water temperature in the fish larval aquaria was $15.3 \pm 0.2^{\circ} \mathrm{C}$. We used 1 video camera (JVC) to record a total number of 40 video sessions. The sample size was 10 per treatment (4 treatments). Individual fish were used for independent observations. All experimental trials were conducted in random order. Use of the 2 predators was also random. Further, before every experimental run, we alternated which of the 2 habitats in the fish larval aquarium was closer to the wall to avoid any systematic differences due to position of the aquarium. During the analysis of the video sessions, we measured time spent in each vegetation type (Fucus vesiculosus versus Cladophora glomerata), number of attacks on zooplankton prey, and total swimming time of the pike larvae. Preliminary observations suggested that the mysid shrimps did not show any distinct distribution pattern during the experiments (authors' unpubl. data).

After the experiment, all pike larvae and mysid shrimps were killed according to Engström-Öst et al. (2005). The fishes were conserved in unbuffered formalin $(37 \%)$. Weight of preserved specimens was measured on a scale (Mettler AE 101-S) and length measured under a binocular microscope (Leica). We calculated a condition index for all fish to ensure their well-being and suitability for the experiments (Ormerod \& Tyler 1990). The length and weight data of the larvae were log-transformed, analysed with linear regression, and residuals used as an index for condition. Negative values denote low condition and positive values denote good condition. Stomach analysis was performed under a binocular microscope. The stomach was removed and carefully opened with 2 sharp forceps in a petri dish. The content was spread out in a small amount of water; thereafter, the zooplankton were identified to species and the numbers counted.

Expt 2: effects of turbidity on growth. In the growth experiment, the pike larvae were exposed to (1) high $(34.9 \pm 1.6 \mathrm{NTU})$ and (2) low turbidity $(5.3 \pm 1.3 \mathrm{NTU})$. Turbidity was measured with a nephelometer (Hach 2100P Portable Turbidimeter). The high turbidity treatment corresponded to $59.3 \pm 3.7 \mu \mathrm{g} \mathrm{chl} \mathrm{al}^{-1}$. Chl a analysis was done according to Engström-Öst (2002). The aim of the experiment was to identify whether high turbidity constrains growth of pike larvae. Turbidity was induced by adding a suspension of the alga Brachiomonas submarina to the experimental water. No algae were added to the low turbidity treatment. Single fish larvae were put into individual 11 white plastic containers. There was no significant difference between the starting weights of larvae put into high and low turbidity water (two sample $t$-test, $t_{14}=1.3, \mathrm{p}=0.22$ ). The containers did not contain stones or plants in order to make the growth environ- 
ments as similar as possible among replicates. The water in each container was changed daily without disturbing the larva, and oxygen saturation was monitored (high turbidity: $128.6 \pm 0.8 \%$, low turbidity: $106.3 \pm 0.4 \%$ ) in the early morning in all experimental units. The light was not switched off during the night, due to the light environment larvae experience in nature. The water temperature was $14.6 \pm 0.03^{\circ} \mathrm{C}$ in the high turbidity units and $14.7 \pm 0.03^{\circ} \mathrm{C}$ in the low turbidity units. The experiment lasted $15 \mathrm{~d}$, and fish larval wet weight $(0.0001 \mathrm{~g})$ was determined with a scale (Mettler AE100) every second day. At the start of the experiment (Day 0), all experimental fish were weighed. For weight measurements, the fish larva was caught in a small plankton net spoon. The spoon was dried and the fish was transferred to a small cup of water of known weight. The water in each weighing originated from the respective experimental unit. The experimental units were cleaned daily by changing the water to pre-aerated, $10 \mu \mathrm{m}$ filtered water of high or low turbidity and larvae were fed by adding $100 \mathrm{ml}$ of dense zooplankton community $(32 \pm 6$ prey $\mathrm{ml}^{-1}$; Synchaeta sp., Acartia bifilosa). The sample size was 8 . None of the fish died during the experimental period. The fish were released to a vegetated shoreline after the experiment.

Light intensity was $5.933 \mu E \mathrm{~m}^{-2} \mathrm{~s}^{-1}$ during the experiment and was monitored once above the experimental units at the end of the experiment (Li1000 Data Logger LiCor). Water conductivity $\left(\mu \mathrm{S} \mathrm{cm}^{-1}\right)$ was measured once during the experimental period (CDM83 Conductivity Meter, Radiometer Copenhagen). Salinity was 6.67 and was calculated as follows: (Conductivity -60.9$) / 163$. Fish larval pellet production was measured once a week. Pellets were collected with a glass Pasteur pipette before the daily cleaning of the aquarium and carefully transferred to plastic petri dishes and counted immediately under a microscope.

All data were tested for normality (Wilk-Shapiro) and homogeneity of variances (Bartlett's test for equal variances). If assumptions were not met, non-parametric tests were employed. All tests were 2-tailed (MANOVA, 2-sample $t$-test), and all data are given as mean \pm SE. For the analyses concerning Expt 1, we used data from the 40 video sessions conducted in turbid water (present study) and 40 sessions from clear water (data obtained from Engström-Öst et al. 2007).

\section{RESULTS}

\section{Expt 1: behaviour in turbid water}

Differences in the behaviour of pike larvae in general, including habitat choice, prey attacks and swimming activity, were highly significant between the treatments (i.e. control, competitor, predator, competitor + predator) and between clear and turbid water (treatment: MANOVA, Pillai's trace $=0.24, F_{9,216}=2.1$, $\mathrm{p}=0.03$; water clarity: Pillai's trace $=0.31, F_{3,70}=10.3$, $\mathrm{p}<0.001$, Fig. 1). The interaction term (Treatment $x$ Water Clarity) was not significant (Pillai's trace $=0.115$, $\left.F_{9,216}=0.96, \mathrm{p}>0.05\right)$.

Between treatments, significant differences were found for the number of prey attacks (MANOVA between subjects, $F_{3,79}=5.3, \mathrm{p}=0.002$; Fig. 1B), whereas habitat choice (Fig. 1A) and swimming activity (Fig. 1C) showed no significant differences $\left(F_{3,79}=\right.$ $0.7, \mathrm{p}>0.05$ and $F_{3,79}=1.3, \mathrm{p}>0.05$, respectively). In contrast, water turbidity affected all fish behaviours (Fig. 1). The number of prey attacks was significantly higher in turbid water than in the control (clear water; $F_{1,79}=22.1, \mathrm{p}<0.001$ ), whereas swimming activity was significantly lower and Cladophora glomerata habitat less preferred in turbid water than in clear water conditions $\left(F_{1,79}=8.8, \mathrm{p}=0.004, F_{1,79}=6.0, \mathrm{p}=0.017\right.$, respectively). The interaction terms (Treatment $x$ Water Clarity) were not significant (prey attacks: $F_{3,79}=1.5, \mathrm{p}>0.05$, swimming: $F_{3,79}=0.6, \mathrm{p}>0.05$, habitat choice: $F_{3,79}=0.4, \mathrm{p}>0.05$ ).

The multiple comparisons showed that prey attacks differed significantly between the control and the visual predator (European perch) treatment (Tamhane's $\mathrm{T} 2, \mathrm{p}=0.012)$, as well as between the competitor treatment (5 Neomysis integer present) and the predator treatment $(p=0.037)$. Swimming activity and habitat choice did not differ between the treatments $(p>0.05)$.

There was a significant trend for higher use of open water by pike larvae in turbid conditions, compared to clear water (2-sample $t$-test, $t_{40}=-1.81, \mathrm{p}=0.07$ ).

The main prey in pike larval stomachs were copepodite stages and adults of the calanoid copepods Acartia bifilosa and Eurytemora affinis, as well as rotifers Synchaeta sp. Stomach analyses of pike larvae showed no differences between the number of copepods (repeated-measures ANOVA, $F_{3,36}=0.5, \mathrm{p}>0.05$ ), or rotifers $\left(F_{3,36}=0.3, \mathrm{p}=0.05\right)$ between the treatments, i.e. with and without a predator respective competitors.

\section{Expt 2: effect of turbidity on weight and growth}

Pike larval weight was significantly lower in high turbidity than in low turbidity (2-sample $t$-test, $t_{63}=$ 4.92, $\mathrm{p}<0.001$, Fig. 2), whereas weight-specific growth rates did not differ between treatments (low turbidity: $6.50 \pm 0.70 \%$ weight $\mathrm{d}^{-1}$, high turbidity: $6.53 \pm 0.65 \%$ weight $\mathrm{d}^{-1} ; 2$-sample $t$-test, $t_{14}=-0.03$, $\mathrm{p}>0.05$ ). Oxygen saturation levels were high in the high turbidity units due to the photosynthesising algae, but levels were also high in the low turbidity 
units throughout the experiment. The weight differences were not reflected in the faecal pellet production of pike larvae, because pellet numbers (low turbidity: $8.2 \pm 0.5$; high turbidity: $8.6 \pm 0.5$ pellets $\mathrm{d}^{-1}$, respectively), were not different between the high turbidity treatment and the low turbidity control (2-sample $t$-test, $\left.t_{15}=-0.51, \mathrm{p}>0.05\right)$.
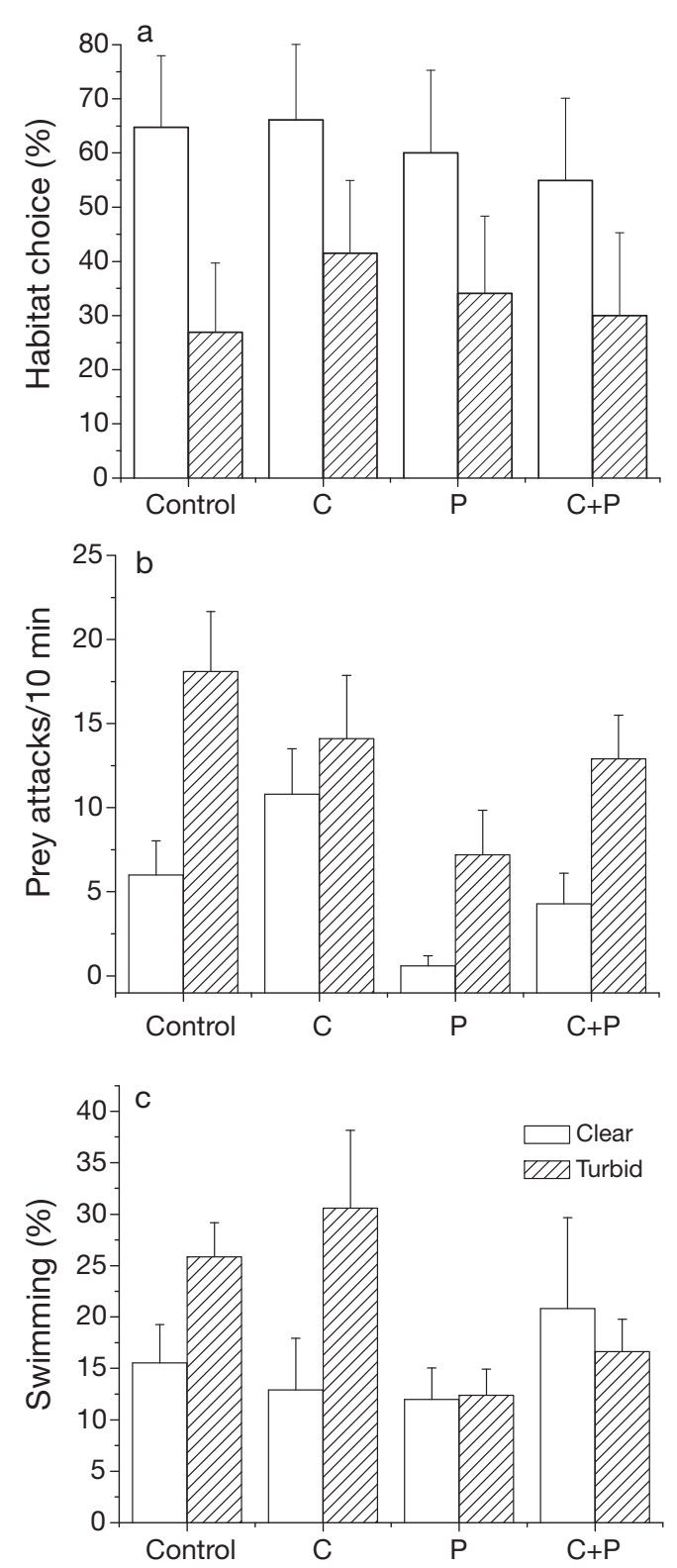

Fig. 1. Esox lucius. (a) Habitat choice as time spent in Cladophora glomerata to total time spent in both habitats (\%), (b) number of prey attacks, and (c) total swimming time (\%), by pike larvae in the different experimental treatments in clear and turbid water. C: mysid shrimps present, P: predator (visual contact), $\mathrm{C}+\mathrm{P}$ : mysid shrimps present + predator (visual contact). Error bars denote SE. Data for the control experiment from Engström-Öst et al. (2007). In general, turbidity had a significant effect on pike larval behaviour

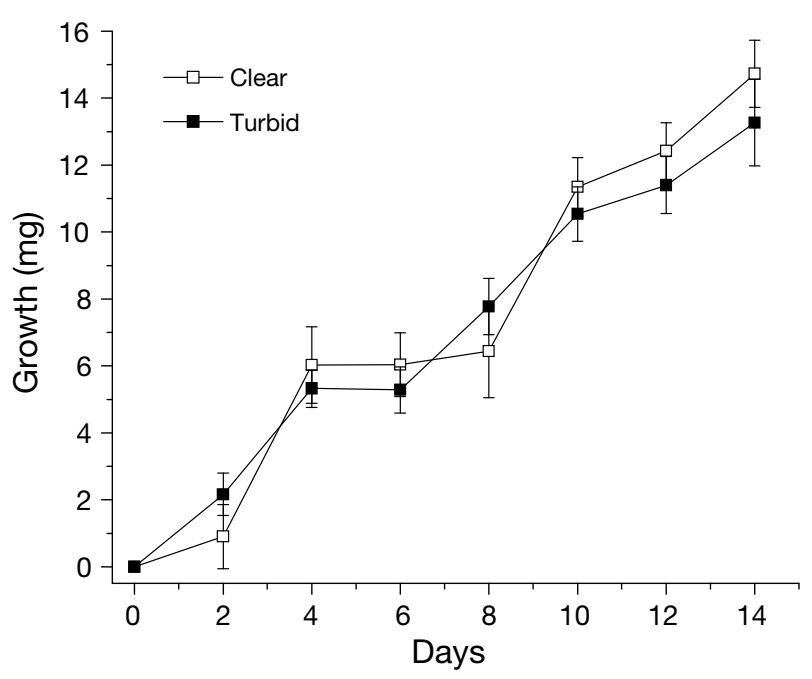

Fig. 2. Esox lucius. Cumulative growth (mg) of pike larvae during 2 wk in low and high turbidity conditions

\section{DISCUSSION}

We demonstrated that pike larvae showed less habitat choice and performed more prey attacks in turbid water than in clear water. In clear water, pike larvae generally show distinctive habitat choice and active feeding (Engström-Öst et al. 2007). In the current study, we also showed that pike larvae gained significantly less weight in high turbidity than in low turbidity. The benefits and disadvantages of the 2 habitats used, i.e. Cladophora glomerata and Fucus vesiculosus, for pike larvae were discussed by Engström-Öst et al. (2007), and will only be described in short here. Newly hatched pike larvae preferred ephemeral filamentous algae (C. glomerata), common in eutrophic waters, to a structurally more robust macroalga, bladderwrack $F$. vesiculosus, which thrives in clean waters. Pike larval survival was also higher in the filamentous algal habitat during predation threat by three-spined stickleback Gasterosteus aculeatus (Engström-Öst et al. 2007), which suggests that the habitat preference of the pike larvae is adaptive when it comes to avoiding predation. Filamentous algae seemingly provide good protection against predation despite their simple morphology.

\section{Behaviour of pike larvae in turbid water}

In the present study, we showed that choice Cladophora glomerata habitat decreased considerably in turbid water compared to experiments conducted in clear water (cf. Snickars et al. 2004, Engström-Öst et al. 2007). Results from previous studies support our 
findings. Reduced water transparency provides shelter against predators (Gregory 1993, Gregory \& Northcote 1993, Maes et al. 1998), and hence the prey is able to redistribute more evenly between habitats (Skov \& Koed 2004). This may include a more active use of open water areas and a reduced use of vegetative shelter (Utne-Palm 2002 and references therein, Snickars et al. 2004). When the larvae perceive less threat, they can engage in activities that would be more risky in clear water, such as diverting effort from seeking shelter (Gregory 1993, De Robertis et al. 2003) to increased foraging (Gregory \& Northcote 1993). Our results support these 2 assumptions, because feeding activity was considerably greater and use of sheltering habitat much lower in turbid conditions than in clear water conditions. Pike larvae also showed less activity in terms of swimming in turbid water, which has also been reported by Sirois \& Dodson (2000). Reduced activity in turbid water may partly be a consequence of larvae perceiving less threat (Abrahams \& Kattenfeld 1997) and partly a reduced need to seek shelter (Vøllestad et al. 1986, Gregory 1993). Pike larvae and other fish decrease their anti-predator behaviour in turbid water (Abrahams \& Kattenfeld 1997, Lehtiniemi et al. 2005). This phenomenon is supported further by our data, because feeding activity decreased significantly in the presence of a visible predator (Perca fluviatilis) compared to the control. In addition, the presence of a competitor (Neomysis integer) clearly increased the foraging activity of pike larvae. We do not know why increased feeding occurs in the presence of mysid shrimps, because growth in pike larvae is inversely related to density of other pike larvae (Grimm \& Klinge 1996).

\section{Effect of turbidity on weight and growth rates}

In the present study, weight gain of larval pike was significantly lower in high turbidity than in low turbidity, whereas weight-specific growth rates showed no differences between the 2 treatments. Evidence from the literature regarding the effect of turbidity on larval growth is inconclusive. Many studies have shown that turbidity reduces growth (Vøllestad et al. 1986, Sweka \& Hartman 2001, Sandström 2004), whereas others found no effect of turbidity on growth (e.g. Van de Meutter et al. 2005), and some reported positive effects (e.g. Sirois \& Dodson 2000). In an experimental study by Lehtiniemi et al. (2005), pike larvae were observed to be stressed in turbid water, since the time until the first prey attack was considerably longer in turbid conditions than in clear water, due to longer acclimation times. We suggest that pike larvae are not able to compensate for lost feeding opportunities, because weight decreased in our study.
We believe that the most likely cause of decreased weight was that pike larvae were not able to capture as much food as in low turbidity, or as a result of increased energy expenditure when searching for food in turbid conditions. On the other hand, the visual contrast between the environment and the prey should increase in turbid water (Utne-Palm 2002), and make it easier for larvae to detect and catch prey, if prey densities are high enough. Larval fish may be less affected by turbidity than adult fish. We have previously shown that pike larvae feed less in turbid water caused by a filamentous non-toxic cyanobacterium (Engström-Öst et al. 2006). In the present study, where high turbidity was caused by the harmless green flagellate Brachiomonas submarina that has been widely used in Baltic studies (e.g. Engström-Öst 2002), pike larvae had a higher attack rate than in clear water but nevertheless gained weight at a slower rate. This indicates that the success of the prey attacks must have been low in high turbidity.

To conclude, water turbidity caused by elevated phytoplankton concentrations showed multiple effects on pike larval weight and behaviour. In turbid water, the larvae performed more prey attacks, and appeared to perceive less threat, since they did not use the vegetation as shelter as much as in clear water. Even though the number of prey attacks was higher in turbid water, the larvae were probably not able to catch as many prey as in clear water, or their energy expenditure was higher, because their weight decreased. On the other hand, even though larval growth would remain at a lower rate than in clear water, pike larvae may benefit from turbid environments, if the predation pressure decreases due to low visibility. Our results show that algae-induced water turbidity affects behavioural aspects of fish larvae both directly and indirectly, and may therefore affect larval survival and potentially the recruitment into the population. Turbidity is a common problem in eutrophicated coastal areas and may have more far-reaching effects on the organisms than previously thought. However, turbidity effects differ widely depending on species, size and distribution, and environmental condition is just one stress factor among many others in eutrophicated systems.

Acknowledgements. We thank H. Strandberg (Trollböle fiskkläckeri) who donated the pike larvae. J. Lindeberg was responsible for animal care. U. Sjölund cultured the phytoplankton. T. Tamminen lent the turbidity meter. We thank E. Immonen for help in the laboratory. Three referees made valuable comments on the manuscript. The Tvärminne Zoological Station provided working facilities and accommodation. The experiments complied with current laws of Finland. Funding by the Academy of Finland (project no. 202382) and Walter och Andrée de Nottbecks Stiftelse is greatly acknowledged. The Animal Care Committee at the University of Helsinki provided permission for the study (no. 69/04). 


\section{LITERATURE CITED}

Abrahams M, Kattenfeld M (1997) The role of turbidity as a constraint on predator-prey interactions in aquatic environments. Behav Ecol Sociobiol 40:169-174

Boyd CE (1982) Water quality management for pond fish culture. Elsevier, Amsterdam

Casselman JM, Lewis CA (1996) Habitat requirements of northern pike (Esox lucius). Can J Fish Aquat Sci 53 (Suppl 1):161-174

Chesney EJ Jr (1989) Estimating the food requirements of striped bass larvae Morone saxatilis: effects of light, turbidity and turbulence. Mar Ecol Prog Ser 53:191-200

Craig JF, Babaluk JA (1989) Relationship of condition of walleye (Stizostedion vitreum) and northern pike (Esox lucius) to water clarity, with special reference to Dauphin Lake, Manitoba. Can J Fish Aquat Sci 46:1581-1586

De Robertis A, Ryer CH, Veloza A, Brodeur RD (2003) Differential effects of turbidity on prey consumption of piscivorous and planktivorous fish. Can J Fish Aquat Sci 60: $1517-1526$

Eiane K, Aksnes DL, Bagøien E, Kaartvedt S (1999) Fish or jellies - a question of visibility? Limnol Oceanogr 44: 1352-1357

Engström-Öst J (2002) The effect of cyanobacteria on plankton and planktivores. PhD dissertation, University of Helsinki

Engström-Öst J, Lehtiniemi M, Jónasdóttir SH, Viitasalo M (2005) Growth of pike larvae (Esox lucius) under different conditions of food quality and salinity. Ecol Freshw Fish 14:385-393

Engström-Öst J, Karjalainen M, Viitasalo M (2006) Feeding and refuge use by small fish in the presence of cyanobacteria blooms. Environ Biol Fishes 76:109-117

Engström-Öst J, Immonen E, Candolin U, Mattila J (2007) The indirect effects of eutrophication on habitat choice and survival of fish larvae in the Baltic Sea. Mar Biol 151: 393-400

> Granqvist M, Mattila J (2004) The effect of turbidity and light intensity on the consumption of mysids by juvenile perch (Perca fluviatilis L.). Hydrobiologia 514:93-101

Gregory RS (1993) Effect of turbidity on the predator avoidance behaviour of juvenile chinook salmon (Oncorhynchus tshawytscha). Can J Fish Aquat Sci 50:241-246

Gregory RS, Northcote TG (1993) Surface, planktonic, and benthic foraging by juvenile chinook salmon (Oncorhynchus tshawytscha) in turbid laboratory conditions. Can J Fish Aquat Sci 50:233-240

Grimm MP, Klinge M (1996) Pike and some aspects of its dependence on vegetation. In: Craig JF (ed) Pikebiology and exploitation. Chapman \& Hall, London, p 125-156

Hällfors G, Hällfors S (1992) The Tvärminne collection of algal cultures. In: Pokki J (ed) Tvärminne Studies 5:15-17. University of Helsinki, Helsinki

Järvenpää M, Lindström K (2004) Water turbidity by algal blooms causes mating system breakdown in a shallowwater fish, the sand goby Pomatoschistus minutus. Proc R Soc Lond B Biol Sci 271:2361-2365

Kotta J, Simm M, Kotta I, Kanoshina I, Kallaste K, Raid T (2004) Factors controlling long-term changes of the eutrophicated ecosystem of Pärnu Bay, Gulf of Riga.

Initial editorial responsibility: Howard Browman, Storebø, Norway (until November 5, 2007); Final editorial responsibility: Matthias Seaman, Oldendorf/Luhe, Germany
Hydrobiologia 514:259-268

Lappalainen A (2002) The effects of recent eutrophication on freshwater fish communities and fishery on the northern coast of the Gulf of Finland, Baltic Sea. PhD dissertation, University of Helsinki

Lehtiniemi M, Engström-Öst J, Viitasalo M (2005) Turbidity decreases anti-predator behaviour in pike larvae (Esox lucius). Environ Biol Fishes 73:1-8

Lehtonen $H$ (1986) Fluctuations and long-term trends in the pike Esox lucius (L.) population in Nothamn, western Gulf of Finland. Aqua Fenn 16:3-9

Ljunggren L, Sandström A (2007) Influence of visual conditions on foraging and growth of juvenile fishes with dissimilar sensory physiology. J Fish Biol 70:1319-1334

Maes J, Taillieu A, Van Damme PA, Cottenie K, Ollevier F (1998) Seasonal patterns in the fish and crustacean community of a turbid temperate estuary (Zeeschelde Estuary, Belgium). Estuar Coast Shelf Sci 47:143-151

Nilsson J, Andersson J, Karås P, Sandström O (2004) Recruitment failure and decreasing catches of perch (Perca fluviatilis L.) and pike (Esox lucius L.) in the coastal waters of southeast Sweden. Boreal Environ Res 9:295-306

Ormerod SJ, Tyler SJ (1990) Assessments of body condition in dippers Cinclus cinclus: potential pitfalls in the derivation and use of condition indices based on body proportions. Ringing Migr 11:31-41

Sandén P, Håkansson B (1996) Long-term trends in Secchi depth in the Baltic Sea. Limnol Oceanogr 41:346-351

Sandström A (2004) The influence of visual conditions on young percids (Percidae spp.). PhD dissertation, Åbo Akademi University

Selén R (1999) Haukikannan muutokset läntisen Suomenlahden ulkosaaristossa 1939-1996-Tutkimuskohteena Nothamnin saaristoalueen haukikanta. MSc thesis, University of Helsinki

Sirois P, Dodson JJ (2000) Influence of turbidity, food density and parasites on the ingestion and growth of larval rainbow smelt Osmerus mordax in an estuarine turbidity maximum. Mar Ecol Prog Ser 193:167-179

Skov C, Koed A (2004) Habitat use of 0+ pike in experimental ponds in relation to cannibalism, zooplankton, water transparency and habitat complexity. J Fish Biol 64: 448-459

Snickars M, Sandström A, Mattila J (2004) Anti-predator behaviour of $0+$ year Perca fluviatilis: effect of vegetation density and turbidity. J Fish Biol 65:1604-1613

Stuart-Smith RD, Richardson AMM, White RWG (2004) Increasing turbidity significantly alters the diet of brown trout: a multi-year longitudinal study. J Fish Biol 65:376-388

Sweka JA, Hartman KJ (2001) Effects of turbidity on prey consumption and growth in brook trout and implications for bioenergetics modeling. Can J Fish Aquat Sci 58: 386-393

Utne-Palm AC (2002) Visual feeding of fish in a turbid environment: physical and behavioural aspects. Mar Freshw Behav Physiol 35:111-128

> Van de Meutter F, Stoks R, De Meester L (2005) Spatial avoidance of littoral and pelagic invertebrate predators by Daphnia. Oecologia 142:489-499

Vøllestad LA, Skurdal J, Qvenild T (1986) Habitat use, growth, and feeding of pike (Esox lucius L.) in four Norwegian lakes. Arch Hydrobiol 108:107-117

Submitted: May 15, 2007; Accepted: November 19, 2007

Proofs received from author(s): April 9, 2008 